\title{
THE NEW YORK AGENGY SHOP FEE AND THE CONSTITUTION AFTER ELLIS AND HUDSON
}

\author{
RICHARD BRIFFAULT*
}

\begin{abstract}
In its recent Ellis and Hudson decisions, the Supreme Court imposed new substantive restrictions and procedural requirements on states that authorize, and public employee unions that utilize, agency shop fees. Focusing on New York State, this study analyzes the consequences for the collection and expenditure of agency fees of the Supreme Court's new emphasis on the First Amendment basis for dissenting employees' rights. The author finds that Ellis and Hudson cast doubt on the constitutionality of some current agency fee practices. He concludes that New York's Public Employment Relations Board will have to take a more active role in policing agency fee standards and procedures than it has until now if the agency fee in New York is to withstand First Amendment scrutiny.
\end{abstract}

$\mathrm{T}$ HE AGENCY shop fee is a device used by many American labor unions to ensure that they receive appropriate financial support from the workers they represent. As collective negotiating representatives, unions win benefits that by their very nature ordinarily cannot be withheld from any particular worker in the group represented (Olson 1965:66-67). Moreover, most labor laws impose duties of fair representation that prohibit unions from discriminating among workers; thus, unions are unable to limit the benefits they obtain for a bargaining unit to union supporters. It follows that "most of the achievements of a union, even if they were more impressive than the staunchest unionist claims," would offer the rational individual worker little incentive to join or pay dues, since whether or not he supports the union he would still get the benefits of the union's work (Olson 1965:76). The agency

* The author is Associate Professor of Law at Columbia University. The New York Public Employment Relations Board provided financial support for some of the research for this paper. shop, which requires nonunion workers in a bargaining unit to remit to the union a sum comparable to union dues, serves to compel the beneficiaries of labor union activity to pay for the benefits they receive.

The agency shop, however, has become fraught with constitutional difficulty. The First Amendment's protection of freedom of conscience and association includes the right to refuse to associate and the right to refrain from supporting objectionable views. Many employees want no part of unions, and oppose the goals of union expenditures. In the public sector, the Supreme Court has found that state authorization to unions to obtain agency fees from public employees, and state involvement in fee collection through payroll deductions and payments to unions, implicate those employees' First Amendment interests.

The Supreme Court has sought to reconcile the individual nonunion employee's First Amendment interest in avoiding an objectionable association with the union's collective interest in obtaining

Industrial and Labor Relations Review, Vol. 41, No. 2 (January 1988). (C) by Cornell University. $0019-7939 / 88 / 4102 \$ 01.00$ 
financial support from all represented workers. In Abood v. Detroit Board of Education, ${ }^{1}$ the Court held that agency fees may be validly collected from public employees and expended for union purposes subject to certain constitutionally mandated limitations. Consistent with Abood, many states have authorized some form of agency fee for unions representing their public employees (Rehmus and Kerner 1980).

The Supreme Court recently handed down two important rulings-Ellis v. Railway Clerks ${ }^{2}$ and Chicago Teachers Union, Local No. 1 v. Hudson ${ }^{3}$ - that clarify points that were ambiguous in the prior case law and tighten restrictions on a state's power to authorize unions to receive and use agency fee payments. As a result, the constitutionality of many state agency fee arrangements may be in question.

This paper examines the constitutionality of New York's agency shop fee law in light of Ellis and Hudson. The New York law was adopted in 1977, the year of the Abood decision. The statutory terms and conditions regulating the collection and use of the fee reflect the state legislature's understanding of the constitutional limitations imposed by Abood. ${ }^{4}$ The New York State Public Employment Relations Board (PERB), in decisions applying the statute to specific fee arrangements, has, until very recently, interpreted the statute according to the same understanding.

I believe that an examination of New York State's experiences may help make clear the implications of Ellis and Hudson for other state labor agencies and unions. This study may also help reveal the emerging vision of nonunion employee rights implicit in those two decisions.

\section{The Constitutional Framework for the Agency Shop Fee}

The Supreme Court has framed its constitutional analysis of the agency shop

\footnotetext{
1431 U.S. 209 (1977).

2466 U.S. 435 (1984).

3 U.S._, 106 S. Ct. 1066 (1986)

${ }^{4}$ Leemhuis v. PERB, 121 AD2d 796, 797 (3d Dept. 1986).
}

fee around two major principles. ${ }^{5}$ First, Congress or a state legislature may legitimately authorize a union to collect fees comparable to union dues from employees who are not members of the union but who share the benefits of union representation. This is the anti-"free rider" principle. As initially developed under the Railway Labor Act and subsequently extended to state and local employees, this principle enables unions to collect fees necessary to defray the costs of negotiating and administering collective bargaining agreements and adjusting and settling grievances. The Court reasoned that since Congress or a state could legitimately seek to promote labor peace through collective bargaining based on exclusive representation, lawmakers could with equal legitimacy seek to bolster collective bargaining by using the agency fee to prevent free riders. ${ }^{6}$ Although the compulsory payment of a fee to a union "might well be thought . . . to interfere in some way with an employee's freedom to associate . . . or to refrain from doing so .... such interference as exists is constitutionally justified by the legislative assessment of the important contribution" of the agency shop to the system of labor relations. ${ }^{7}$

Second, the First Amendment precludes government authorization of union expenditure of agency shop fees for political and

\footnotetext{
${ }^{5}$ First Amendment questions arise only in the context of government action; consequently, an agency shop agreement entered into between a private sector employer and a union will ordinarily not present a constitutional issue. See, e.g., Price $v$. United Automobile Workers, 795 F.2d 1128 (2d Cir. 1986); but cf. Beck v. Communications Workers, 800 F. 2d 1280 (4th Cir. 1986).

The first three Supreme Court cases that considered agency shop fee arrangements arose under the federal Railway Labor Act. Although that Act affects only private employees, the Court has interpreted it as promoting rather than merely permitting agency fee agreements-Railway Employees v. Hanson, 351 U.S. 225 (1956) - and has, thus, treated the Act as raising constitutional questions. The other principal Railway Labor Act cases decided prior to Ellis are Machinists v. Street, 367 U.S. 740 (1961) and Railway Clerks v. Allen, 373 U.S. 113 (1963). The first agency fee case involving a public employer was Abood $v$. Detroit Board of Education, 431 U.S. 209 (1977).

6431 U.S. at $220-26$.

${ }^{7} \mathrm{Id}$. at 222.
} 
ideological purposes to which the fee payer is opposed. A public sector union receiving agency fees is not barred from spending funds for political purposes, but "the constitution requires .. . that such expenditures be financed from charges, dues, or assessments paid by employees who do not object to advancing those ideas and are not coerced into doing so against their will by the threat of loss of governmental employment."8 Thus, although the Supreme Court validated union collection and expenditure of agency fees to prevent "free riding" on collective bargaining benefits, workers are not deemed "free riders" when unions engage in political spending.

Within this basic analytic framework, recent cases have focused on two issues: substantive limits on the use of the agency fee, and procedures necessary to protect those fee payers who object to the political uses to which their payments may be put.

\section{Substantive Limits on Fee Uses}

The line between financing collective bargaining and supporting political programs will often be difficult to draw. Nor is it easy to classify the manifold union activities that are neither collective bargaining nor politics but rather fall between these extremes. Although there are brief references to this dilemma in the early agency fee cases, the first sustained effort to articulate a standard for testing the legitimacy of agency fee expenditures and applying that standard to specific activities came in 1984 in Ellis v. Railway Clerks.

In Ellis, the Court held that the permissibility of union expenditures of agency fees turns on "whether the challenged expenditures are necessary or reasonably incurred for the purpose of performing the duties of an exclusive representative of the employees in dealing with the employer on labor-management issues."9 In

\footnotetext{
${ }^{8} \mathrm{Id}$. at $235-36$.

9466 U.S. at 448. Ellis arose under the Railway Labor Act, and the Court's test was nominally a matter of statutory interpretation. Since the anti-free rider principle has been held to explain both
}

applying this test to specific expenditures, the Court followed three criteria.

First, agency fees may be used to finance activities that support the corporate existence and operation of the union even though not directly connected to collective bargaining, as long as the activities ultimately relate to the union's duties as a representative of the bargaining unit. Second, expenditures not connected to the representation of the bargaining unit, even when they strengthen the union and are not political or ideological, are not authorized if dissenters object. Finally, the Court would not be limited by the union's budget categories and distinguished representation-related spending from non-representation-related spending even within a particular category of union activity.

Ellis upheld expenditures for three union functions-conventions, social activities, and publications - that the Supreme Court deemed "activities or undertakings normally or reasonably employed to implement or effectuate the duties of the union as exclusive representative of the employees in the bargaining unit." The Court had "very little trouble" in finding conventions permissible: "Surely, if a union is to perform its statutory function, it must maintain its corporate or associational existence, must elect officers to manage and carry on its affairs, and may consult its members about overall bargaining goals and policies." Similarly, social activities, at least those in which expenses are held to a minimum, were deemed to be "sufficiently related" to collective bargaining and a "standard feature of union operations." Publications were seen as a reasonable method for the union to communicate with its constituents and were, thus, connected to the union's "representational obligations." 10

Congress's intention in authorizing the agency fee and its constitutional power to do so, the Ellis standard may also be of constitutional magnitude. Each of the expenditures the Ellis Court found covered by the anti-free rider rationale and authorized by Congress as a statutory matter was also found to withstand constitutional challenge.

${ }^{10} \mathrm{Id}$. at $448-51$. 
The Court gave short shrift to the constitutional objections, perceiving "little additional infringement of First Amendment rights beyond that already accepted, and none that is not justified by the governmental interests behind the union shop itself." The Court, in effect, treated plaintiffs' objections to these expenditures as no more than objections to compulsory support of unions, which, when limited to "the realm of collective bargaining," stated no First Amendment violation. ${ }^{11}$

On the other hand, the Court readily determined that union organizing efforts and certain litigation expenses were not authorized. As the Court noted, if an agency shop agreement is in place, the union has already organized the bargaining unit. The focus of organizing activity would be either nonmembers within the unit or employees in other units. As to the former, the Court reasoned "it would be perverse" to permit the union "to charge to objecting non-members part of the costs of attempting to convince them to become members." 12 The organizing of other bargaining units was treated as similar to union political activity; whereas extra-unit organizing might be said to bolster the union as a bargaining representative by strengthening the union generally, the connection between extra-unit organizing and the representation of the dues payer was deemed to be too "attenuated" to be supportable. Moreover, like political activity, extra-unit organizing was deemed to fall outside the free rider rationale. An anti-union employee could not be said to "free ride" on the benefits of expanded union strength if he did not view such expansion as a benefit. ${ }^{13}$

Similarly, the Court applied the principle of representation of the bargaining unit to limit the extent to which nonunion employees may be charged for litigation expenses. Litigation costs "incident to negotiating and administering the contract or to settling grievances and disputes

\footnotetext{
${ }^{11} I d$. at $455-57$.

12 Id. at 452 n. 13.

${ }^{13} I d$. at $451-53$.
}

arising in the bargaining unit," "fair representation litigation arising within the unit," "jurisdictional disputes with other unions," and "any other litigation before agencies or in courts that concern bargaining unit employees and normally conducted by the exclusive representative" may be charged to agency fee payers. "The expenses of litigation not having such a connection with the bargaining unit" may not be paid out of agency fees. In the Ellis case, which concerned clerical employees of Western Airlines, this exclusion meant that "objecting employees need not share the costs of the union's challenge to the legality of the airline industry mutual aid pact; of litigation seeking to protect the rights of airline employees generally during bankruptcy proceedings; or of defending suits alleging violation of . . . the Civil Rights Act of 1964."14

The Ellis Court's third theme, of pursuing the bargaining unit representation versus non-representation dichotomy through all expenditures and not simply relying on union expense categories, may be seen in the Court's treatment of publication costs. Although the Court generally upheld the use of agency fee money to fund publications, under the agency agreement at issue the union had agreed not to charge objecting employees for the portion of the union magazine devoted to "political causes." The Court stated that the union's voluntary limit on charges to objecting employees was "an important one":

If the union cannot spend dissenters' funds for a particular activity, it has no justification for spending their funds for writing about that activity. By the same token, the Act surely allows it to charge objecting employees for reporting to them about those activities it can charge them for doing. ${ }^{15}$

The Court's treatment of litigation expenses is also clearly marked by the effort to allocate litigation costs between repre-

\footnotetext{
${ }^{14} \mathrm{Id}$. at 453 .

${ }^{15} \mathrm{Id}$. at 451 .
} 
sentation-related and non-representationrelated matters. ${ }^{16}$

\section{Agency Fee Procedures}

The Court has addressed two procedural issues: What is the status of disputed agency fee payments pending resolution of the dissenter's claim to a right to withhold funds? How is a dissenter's objection to be presented and resolved?

Status of contested fee payments. In Machinists $v$. Street and Railway Clerks $v$. Allen the Court indicated that dissenting employees' interests could be satisfied by "restitution to each individual employee of that portion of his money which the union expended, despite his notification, for the political causes to which he had advised the union he was opposed." 17 The political activities' share of the union's total budget would be calculated and the dissenting employee would be entitled to have returned the equivalent proportion of his agency fee.

The Court's use of the term "restitution" in these two Railway Labor Act cases suggested that the Act and, implicitly, the First Amendment, could be satisfied by an initial collection of agency fees subject to a later return of moneys equivalent to the dissenters' coerced political contribution. In Abood, the Court reviewed the Railway

\footnotetext{
${ }^{16}$ On the other hand, the Court's commitment to piercing budget categories and apportioning expenses did not extend to its discussion of the union convention. As Justice Powell pointed out in his separate opinion, a number of prominent politicians made speeches at the union's latest convention, and he read the Act and the First Amendment as denying the union the authority to use compulsory dues to defray that portion of the convention marked by such political activity. 466 U.S. at 459-61. Justice White, writing for the rest of the Court, however, permitted the union to apply agency fees to the costs of the convention without limitation and did not address Justice Powell's objection.

In addition, the Court considered but did not decide whether the union could add agency fees to the general fund used to pay a $\$ 300$ death benefit to the designated beneficiary of any member or nonmember required to pay dues or fees to the union. $I d$. at $453-55$.

17367 U.S. at 775. See also 373 U.S. at 121.
}

Labor Act decisions and referred to the "appropriateness" of the remedies sketched in Street and Allen but did not pass directly on what remedy would suffice to protect the constitutional rights of public employees paying the agency fee. ${ }^{18}$

In Ellis and Hudson the Court changed its approach and held "the pure rebate approach is inadequate." 19 Under this new interpretation, the return of the political share of the agency fee, even with interest, did not mitigate effectively the harm done through the use of such moneys. Under a rebate scheme "the union obtains an involuntary loan for purposes to which the employee objects." The only justification for such coerced borrowing was "administrative convenience." The existence of other administrative alternatives, such as advance reduction of dues or interestbearing escrow accounts, eliminated any need for even a temporary use of dissenters' funds to subsidize political or ideological views they oppose. ${ }^{20}$

In Hudson the Court cautioned that the escrow of 100 percent of a dissenter's dues payment is not constitutionally required. That requirement would deprive the union of access to some agency fee payments that it is "unquestionably entitled to retain." 21 If the union can establish the portion of the fee that is used for clearly authorized activities, there is no need to escrow that amount. But if the union chooses to escrow less than the entire agency fee paid by an objector, "it must carefully justify the limited escrow" on the basis of an independent audit of the union's expenditures. ${ }^{22}$

Procedures for objectors. In Street, the Court placed the burden of taking the initial step in preventing the improper disbursement of funds on the objecting employee: "[D]issent is not to be presumed-it must affirmatively be made

\footnotetext{
18431 U.S. at $237-42$.

19466 U.S. at 443.

${ }^{20} I d$. at 444 .

21106 S.Ct. at 1078.

${ }^{22} I d$. at n. 23.
} 
known to the union." ${ }^{23}$ The union has the right to collect agency fees and to spend them for any lawful purpose, including ideological or political activities, until an employee specifically notifies the union of his objection to the use of his money for such activity. In Allen, the Court eased the dissenter's notice burden by holding that an employee's general statement of opposition to any political expenditures by the union would suffice to give notice; objection to particular expenditures would not be required. ${ }^{24}$

Ellis and Hudson continued to place the burden of initial objection on the dissenting employee, but Hudson held the union is obligated to give potential objectors "sufficient information to gauge the propriety of the union's fee." 25 The union must disclose to nonmembers some information concerning the uses to which the fee is put as a precondition to the collection of the fee. Moreover, Hudson mandated that once an expenditure is objected to, the burden of proving the proportion of political to total union expenditures is on the union. ${ }^{26}$

Finally, Hudson added the new procedural requirement that employee objections receive a prompt hearing by an impartial decision-maker. The Court was sharply critical of the procedure provided by the Chicago Teachers Union in the Hudson case: an initial consideration of the dissenter's objection by a union official, review by the union executive committee and executive board, and, as a final step, review by a union-selected arbitrator. The union's internal review procedure was fatally flawed because it was "entirely controlled by the union, which is an interested party."27 The Court rejected the union's contention that "ordinary judicial remedies"-namely, a civil suit in state court-would suffice to protect an objector's interests. Review by union officials and a union-selected arbitrator failed

\footnotetext{
23367 U.S. at 774.

24373 U.S. at $118-19$

25106 S.C.t. at 1076.

${ }^{26} I d$. at 1075, quoting Allen, 373 U.S. at 122.

27 Id. at 1077 .
}

for lack of impartiality; requiring a dissenter to seek vindication in court was not adequate to meet the requirement of a "reasonably prompt" decision unless the state chose to provide an "extraordinarily swift judicial review" for dissenter challenges. ${ }^{28}$ The Court did not require any specific procedure, but underlined the need for an "expeditious, fair and objective" mechanism that would facilitate nonmember employees' ability to protect their rights. ${ }^{29}$

Ellis and Hudson are striking in their renewed emphasis on the First Amendment basis for the dissenter's rights, the burden on the union to prove that contested expenditures are representationrelated and not merely non-political, and the extension of First Amendment concerns to procedural questions. Underlying the Court's requirements of notice of union spending, advance reduction or escrow, and prompt review by an impartial decision-maker is its concern that the agency fee-even when justified by the governmental concern to prevent "free riders"-impinges on First Amendment rights and that procedures protecting the interests of dissenting employees are, thus, constitutionally mandated.

\section{The New York Agency Shop Fee Deduction}

\section{Authorization for the Deduction}

The New York State Legislature first authorized the agency shop fee in 1977 when it amended section 208 of the Civil Service Law. Subsection 3(a) of Section 208 provides that public employee organizations recognized or certified as exclusive representatives of negotiating units representing most state employees "shall be entitled to have deducted from the wage or salary of the employees in such negotiating unit who are not members of said employee organization the amount equivalent to the dues levied by such employee organization" and to have that deduction transmitted to the employee organization.

\footnotetext{
${ }^{28} I d$. at $1076-77$ n. 20.
}

${ }^{29} \mathrm{Id}$. at 1076. 
Subsection 3(b) provides that unions representing local government employees are "entitled to negotiate" for the agency shop fee arrangement.

Section 208(3) also contains a proviso that limits the applicability of the agency shop fee deduction to those employee organizations that have

established and maintained a procedure providing for the refund to any employee demanding the return of any part of an agency shop fee deduction which represents the employee's pro rata share of expenditures by the organization in aid of activities or causes of a political or ideological nature only incidentally related to terms or conditions of employment.

PERB has consistently held that the establishment and maintenance of a valid refund procedure is a "statutory prerequisite" for the "grant of a long-withheld privilege."30 PERB has asserted the authority to order the return of agency shop deductions as a remedy when a union has failed to establish and maintain a valid refund procedure, and that assertion has been upheld by the courts. ${ }^{31}$

\section{Substantive Limitations on the Uses of Agency Shop Fees}

Section 208(3) on its face requires that a refund be available only for expenditures in support of "activities or causes of a political or ideological nature only incidentally related to terms and conditions of employment." There is no state judicial or PERB gloss on the meaning of the quoted language and no cases directly deciding which activities or causes are "political or ideological" and which are not within the

\footnotetext{
${ }^{30}$ United University Professions, Inc. (Eson), 11 PERB Para. 3068 (1978). Prior to enactment of section 208(3), the New York courts had upheld PERB's finding that the agency fee violated the Civil Service Law's guarantee to public employees of the right to refrain from joining in employee organizations. Matter of Farrigan v. Helsby, 42 AD2d 265 (3d Dept. 1973).

${ }^{31}$ Public Employees Federation v. PERB, 93 AD2d 910 (3d Dept. 1983) (upholding PERB power to order refund, although modifying particular refund order); United University Professions, Inc. v. Newman, 86 A.D.2d 734 (3d Dept.), lv. app. den. 56 NY2d 504 (1982).
}

meaning of the refund proviso. ${ }^{32}$ In particular, there has been no reported consideration of whether the phrase "only incidentally related to terms and conditions of employment" limits the political activities refund so that political or ideological expenditures that are directly related to terms and conditions of employment are not refundable; or whether all "activities or causes of a political or ideological nature" within the meaning of the statute are by definition only incidentally related to terms and conditions of employment.

PERB and the courts have given indirect attention to the issue of whether agency fee moneys may be used to fund union benefit programs, such as insurance, medical, or accidental death and dismemberment policies. PERB has held that where agency fee payments are used to defray the cost of such programs nonunion employees who are compelled to contribute must also be entitled to the benefit or the union will be required to refund their contribution. ${ }^{33}$ Although the union's right to use the agency fee for such purposes was not discussed, such a use appears to have been implicitly upheld. ${ }^{34}$ Similarly, the only requirement

${ }^{32}$ In Handy $v$. Westbury Teachers Ass'n, 104 AD2d 923, 926 (2d Dept. 1984), the Court found that an employee's claim that section 208(3) permits the union to use agency shop fees for purposes other than collective bargaining in violation of the First Amendment stated a proper cause of action but that the record was insufficient to permit an adjudication of the merits.

${ }^{33}$ See, e.g., United University Professions, Inc. (Eson), 12 PERB Para. 3117 (1979), aff'd Matter of United University Professions, Inc. v. Newman, 80 AD2d 23, 26 (3d Dept. 1981); United Federation of Teachers, Local 2 (Barnett), 16 PERB Para. 3052 (1983).

${ }^{34}$ In Eson, the Board held that the use of agency fee payments to secure insurance benefits solely for members of the union interfered with, restrained, and coerced the employee in the exercise of his right not to join or participate in a union, in violation of section 209-a (2)(e) of the Civil Service Law. The Board deemed it "not necessary to determine" whether insurance benefits were a permissible use of union dues. The Board's order indicated that providing benefits to all dues payers-union members and nonmembers-would cure the violations. Similarly, in Barnett, the Board treated the union's 
PERB imposed on a union that allocates agency fee payments to the support of its publications was to take reasonable efforts to make available to fee-payers those publications providing "substantial economic or job-related benefit to unit employees." 35

Although PERB has never expressly addressed the issue of agency fee money for union benefit programs, these cases suggest that for purposes of section 208(3) there may be no gray area between political activity and collective bargaining-all union activities that are not political or ideological (and arguably some that are) may be funded out of the agency fee and are not refundable to dissenting employees.

\section{Procedures for Implementing the Fee Deduction}

Status of contested fee payments. In 1978, in United University Professions, Inc. (Eson), ${ }^{36}$ PERB held that the refund requirement of section 208(3) could be satisfied by a union procedure of collecting agency shop fees during the course of its fiscal year and refunding to objecting employees their pro rata share of expenditures in support of political and ideological causes after the end of the fiscal year. In 1984, following Ellis, PERB overruled UUP(Eson). The Board initially determined that section

defense that it was providing insurance to a nonmember dues payer as an adequate defense to an improper practice charge. The validity of the union's practice of using dues to pay for insurance benefits was not challenged.

In the Appellate Division's affirmance of Eson, the court ruled that the Board's requirement that either the benefits be equitably provided or the nonmember dues payer receive a refund was reasonable, "particularly when redress through the refund mechanism would not be available unless the challenged funding was for political or ideological activity." $80 \mathrm{AD} 2 \mathrm{~d}$ at 26 . Implicitly, then, insurance benefits were not "political or ideological activity" and therefore not unauthorized by section 208(3) so long as they were equitably provided to all dues payers.

${ }^{35}$ United Federation of Teachers, Local 2 (Barnett), 17 PERB Para. 3023 (1984).

${ }^{36} 11$ PERB Para. 3068 (1978); 11 PERB Para. 3074 (1978).
208(3) required an escrow in an interestbearing account of 100 percent of the agency shop fee of nonmembers who object to political spending. ${ }^{37}$

PERB then changed its position in 1985 and held that section 208(3) could be satisfied by the advance reduction of a portion of an objector's fee. In United University Professions, Inc. (Barry), ${ }^{38}$ the Board considered a challenge to a union procedure that provided for advance reduction of an annual fee. The reduction was based on the union's approximation of the expenditures it and its affiliates would make during that year for refundable activities. That approximation, in turn, was based on the union's expenditures during the latest fiscal year for which there was a completed and available audit. After a year-end audit, the actual expenditures for refundable purposes were calculated and adjustments to the advance reduction made as appropriate. PERB dismissed the contention that any refund procedure that failed to provide for a 100 percent escrow was invalid on its face and held that "the statute does not mandate any particular form of procedure" and "should be construed as permitting any refund procedure ... which affords appropriate protection to the interests of non-members." 39

Although it did not specifically approve the UUP advance reduction method, the Board held that advance reduction of a portion of the fee could suffice. The Board noted that when assessing the validity of a particular advance reduction procedure, "the basis upon which the amount of the advance reduction is determined" would be an important factor, but it did not comment on the basis used in the plan before it, nor did it address the fact that under the union plan, part of the refundable portion of the objector's dues would be temporarily used by the union.

Procedures for objectors. PERB has construed section 208(3) to place the initial

\footnotetext{
${ }^{37}$ United University Professions, Inc. (Barry), 17 PERB Para. 3098 (1984).

38 18 PERB Para. 3063 (1985).

${ }^{39}$ Id.
} 
burden of objecting to union spending on the nonmember, although "an expression of generalized opposition to political or ideological expenditures unrelated to collective bargaining is all that may be demanded in a refund procedure." 40 Moreover, the union is required "to provide timely notice of its refund procedure to all persons paying an agency shop fee." 41 When an employee objects to the use of an agency shop fee, the union must bear the burden of justifying its assessment and establishing that the fees are not being expended for impermissible purposes, and this burden extends to funds a local union has forwarded to its national or state affiliates. ${ }^{42}$

PERB has held that a union must provide objectors with "an itemized, audited statement of the complete receipts and expenditures of the union and any of its affiliates which receive, either directly or indirectly, any portion of its revenues" from the union's agency fees, together with the basis for the union's determination of the amount of the refund, including identification of those items of expense determined by the union and its affiliates to be refundable. ${ }^{43}$ The duty to provide financial information applies whether or not the objector has requested such information. ${ }^{44}$

Although most unions have provided objectors with an internal appeals procedure-typically involving two appellate steps within the union hierarchy and a third and final step of decision by a neutral appointed by the union-PERB has held that neither the appointment of a neutral nor any other internal union procedure, other than the opportunity to apply for a refund, is mandated. Rather,

\footnotetext{
${ }^{40}$ Warner v. Board of Education, 99 Misc. 2d 251, 258 (Sup. Ct. Monroe Co. 1979).

41 Public Employees Federation (Kahn), 15 PERB Para. 3011 (1982).

${ }^{42}$ Warner $v$. Board of Education, supra, 99 Misc. 2d at 258,259 .

${ }^{43}$ United University Professions, Inc. (Barry), 13 PERB Para. 3090 (1980).

${ }^{44}$ Professional Staff Congress (Rothstein), 15 PERB Para. 3012 (1982). Failure to provide financial information may result in a refund of the objector's entire agency fee payment.
}

PERB has stated that the opportunity for a "plenary action in court" can satisfy an objector's right to an impartial review of the union's decision. ${ }^{45}$

Where an appellate procedure is provided, however, PERB has passed on its sufficiency. Thus, PERB has held that such a procedure must be "expeditious"with "expeditious" defined as requiring a final decision within one year of the objection. ${ }^{46}$ Any appellate procedures must have jurisdiction over agency fees forwarded to a union's affiliates. ${ }^{47}$ The union must absorb the cost of resort to the neutral; an early attempt to require the objecting employee to pay one-half of the neutral's costs was rejected. ${ }^{48}$ On the other hand, the union may have a free hand in selecting the neutral, and the union may request the neutral to have the hearing at a particular site that is more convenient to the union than to the objector, so long as it remains reasonably accessible to the objector. 49

PERB will not review the conduct or rulings of the neutral. In Hampton Bays Teachers Ass' $n, 50$ PERB ruled that it lacked jurisdiction to review the correctness of the amount of the refund. PERB drew an analogy between the question of the amount of the refund and the right to a particular benefit promised by a collectively negotiated agreement: The Legislature had denied the Board jurisdiction to consider alleged violations of an agreement; by implication, the Board stated, it lacked jurisdiction to consider the amount of the refund. Thereafter, the Board extended Hampton Bays to bar all review of the conduct or rulings of the neutral, "as they are essentially a part of the challenge

\footnotetext{
${ }^{45}$ Hampton Bays Teachers Ass'n, 14 PERB Para. 3018 (1981).

${ }^{46}$ United University Professions, Inc. (Eson), 12 PERB Para. 3093 (1979). Undue delay may be grounds for a refund. United University Professions, Inc. (Barry), 16 PERB Para. 3040 (1983).

47 United University Professions, Inc. (Eson), 11 PERB Para. 3068 (1978) and 11 PERB Para. 3072 (1978).

${ }^{48} \mathrm{Id}$.

${ }^{49}$ United University Professions, Inc. (Barry), 17 PERB Para. 3031 (1984).

${ }^{50}$ Hampton Bays Teachers Ass'n, supra note 45.
} 
to the correctness of the amount of the refund." 51 The actions of the neutral and the sufficiency of the refund may only be challenged in a plenary court action.

\section{The New York Agency Shop Fee Deduction After Ellis and Hudson}

\section{Substantive Limitations on the Uses of the Fee}

In Ellis, as noted above, the Supreme Court invalidated the use of agency payments for certain nonpolitical and nonideological activities, including union organizing expenditures, litigation expenses connected to a union challenge to an industry-wide employee mutual aid pact, union litigation of the rights of employees generally during bankruptcy proceedings, and the union's defense of civil rights suits. As such, Ellis is more restrictive than New York's authorization to unions, in Section 208(3), to use fees for all purposes other than those "activities or causes of a political or ideological nature only incidentally related to terms and conditions of employment."

Admittedly, Ellis's treatment of those expenses was only for the purpose of assessing whether they were authorized by the Railway Labor Act, and the Court's holding with respect to the organizing and litigation expenses was limited to a determination that there was no statutory authorization. Nevertheless, the Court's discussion of these fee uses, and its emphasis that agency fee moneys be limited to purposes connected to the union's organizational existence and its representation functions, was built around an attempt to mark out the scope of the anti-free rider rationale and is, thus, clearly of constitutional dimension.

It is not certain how far Ellis's tightening up on the permissible uses of agency fees is to apply in the public sector. As the Court recognized in Abood, the line between representation-related and nonrepresentation-related expenditures "may

\footnotetext{
${ }^{51}$ United University Professions, Inc. (Barry), 14 PERB Para. 3099 (1981).
}

be somewhat hazier" in the public sector than in the private. Abood acknowledged that the achievement of union goals in the public sector "may require not merely concord at the bargaining table, but subsequent approval by other public authorities; related budgetary and appropriation decisions might be seen as an integral part of the bargaining process." 52 The Court declined to attempt to define the scope of representation-related public sector expenditures, but other courts have permitted unions to use agency fees for legislative lobbying activities "pertinent to the duties of the union as a bargaining representative." 53

Ellis and Abood, thus, send conflicting signals concerning permissible union uses of agency fees. One solution to this problem would be for PERB to issue guidelines indicating which expenditures may be properly charged to nonmembers and which may not. Such interpretive guidelines could serve two important functions.

Section 208(3), as written, presumes that all union expenditures other than political or ideological activity "only incidentally related" to labor concerns will be permitted. Although the distinction between collective bargaining and political activity is, at best, elusive in the public sector (Rehmus and Kerner:1980; Summers:1975), it is the distinction the Supreme Court insists upon. Ellis indicates that agency fee legislation may only authorize representation-related expenditures, and section 208(3)'s broad language may have to be narrowed to survive Ellis. On the other hand, given Abood's recognition that some political activity is indeed intertwined with public sector bargaining, interpretive guidelines could serve the vital purpose of educating the courts as to how and when union lobbying, legislative, public information, and other arguably political activities serve legitimate bargaining goals. In other words, interpretation

\footnotetext{
52431 U.S. at 236.

${ }^{53}$ See, e.g., Robinson v. New Jersey, 741 F.2d 598 (3d Cir. 1984); Board of Education v. Boonton Education $A s s ' n, 494$ A.2d 279 (N.J. 1985).
} 
by an expert agency could both help tailor the statute to constitutional norms and, by informing a reviewing court as to how those constitutional norms ought to be applied given the realities of public sector collective bargaining, permit the application of the statute in a manner consistent with the actual practice of public employeremployee relations.

PERB, however, has so far declined to pass on the substantive propriety of agency fee expenditures, claiming it lacks jurisdiction to consider the standards used by a union in determining the amount of a refund. ${ }^{54}$ The Board has similarly declined to pass on the substantive rulings of the union-appointed neutral, and the courts have deferred to the agency's interpretation of its jurisdiction. ${ }^{55}$

PERB's determination that it lacks jurisdiction to pass on the substantive dimensions of the agency shop refund is unpersuasive. Unlike the review of disputes under a collective agreement, review of the merits of a refund claim is not expressly barred by statute. The standards for use of the agency fee involve statutory interpretation of the Civil Service Law-a subject of PERB expertise-not contract interpretation. Moreover, the adequacy of the refund procedure, which is a statutory prerequisite to the agency shop fee deduction, turns in part on whether the procedure yields substantively proper results.

The value of guidelines that could interpret the statute in order to save it and could educate the courts in future constitutional challenges argues for PERB's reconsideration of its current unwillingness to look into the correctness of a refund. If PERB continues to adhere to its current analysis of its jurisdiction, the only way to meet any doubts about the scope of the agency fee authorization will be to amend the statute or to await the results of a federal court challenge.

\footnotetext{
${ }^{54}$ East Moriches Teachers Ass'n, 14 PERB Para. 3056 (1981).

${ }^{55}$ Bodanza v. PERB, 128 Misc. 2d 786 (1985), aff'd 119 AD2d 917 (3d Dept.), lv. app. den. 68 NY2d 607 (1986).
}

\section{The Refund Mechanism}

PERB has not mandated any specific refund mechanism. Instead, it has interpreted the statute to allow either an escrow or an advance reduction of duesthe two methods presented by the $\mathrm{Su}$ preme Court-and has stated it will proceed on a case-by-case basis in assessing whether a particular refund mechanism adequately protects dissenters' interests.

PERB has indicated that a 100 percent escrow or cessation of all dues collection will not be required. Although this position is consistent with Hudson's holding that a 100 percent escrow is not constitutionally necessary, a partial escrow leaves open the possibility of a nonmember's overpayment, which would not be refunded until the following year. This contingency was apparent on the face of the union plan recently reviewed by the Board in UUP (Barry).56 Though the Supreme Court has maintained that "absolute precision in the calculation of the charge to non-members cannot be expected or required" 57 and has stated that a union "cannot be faulted for calculating its fee on the basis of its expenses during the preceding year,"58 the Court has also emphasized that even the temporary improper use of a small coerced contribution infringes First Amendment rights. ${ }^{59}$

One approach that would permit a partial escrow while protecting dissenters' interests would be to require any union using a partial escrow plan to add to its base year calculation of rebatable expenditures a "cushion" or margin of safety-a specific increment of 5 percent or 10 percent or 15 percent. A single "cushion" could be required for all unions, or a different cushion for different unions or categories of unions. The cushion could be based on an examination of the volatility of union budgets - for example, how dramatically has the political portion

\footnotetext{
${ }^{56}$ See text at notes 38 and 39 , supra.

${ }^{57}$ Id. at 1076 n. 18 (quoting Railway Clerks v. Allen, 373 U.S. at 122).

${ }^{58} \mathrm{Id}$.

${ }^{59} I d$. at 1075 .
} 
of union expenditures changed from year to year? Is last year's political share a reasonably good predictor of this year's? The cushion could also be based not on the prior year's budget but on the highest percentage the union has ever devoted to political activity.

Given the importance of the rights at stake, the benefits of avoiding the consumption of time and energy in protracted litigation, and the kinds of data that would go into making the "cushion" determination, a rule-making proceeding would be desirable. A PERB rule could either set or require a specific percentage addition to the base year political percentage to be added by all unions, or it could provide a formula each union could use in calculating its particular margin of safety.

\section{Fair Notice of the Right to a Refund}

PERB has required unions to give fee payers notice of the procedure for a refund. PERB has also required the union to provide objectors with a detailed financial statement of its receipts and expenditures and those of its affiliates and the basis for its determination of the amount of the refund. Hudson indicates that those two steps will have to be combined into one-that financial information sufficient to gauge the propriety of the union's fee has to be provided before the fee is collected and spent. In Hudson the Court held that "leaving the non-union employees in the dark about the source of the figure for the agency fee-and requiring them to object in order to receive information" is inadequate to protect nonmembers' First Amendment rights. ${ }^{60}$

This pre-objection disclosure of financial information need not be as detailed as the financial information currently required to be provided to objectors, but constitutionally mandated disclosure surely would include the major categories of expenses, as well as verification by an independent auditor. ${ }^{61}$ Disclosure would also have to apply to the activities of

\footnotetext{
${ }^{60} 106$ S. Ct. at 1076.

${ }^{61} I d$. at n. 18.
}

affiliated state and national labor organizations that receive agency shop fee moneys from a union. 62

\section{Review by an Impartial Decision-Maker}

Hudson establishes that an agency shop fee procedure must include a "reasonably prompt decision by an impartial decisionmaker" on objections by nonunion employees. The Court held that neither union procedures consisting of internal appeals and reference to a union-selected arbitrator nor ordinary judicial remedies are sufficient to meet this requirement. Thus, Hudson treated as constitutionally inadequate the kind of objection procedure that PERB has found satisfactory for purposes of section 208(3). PERB has repeatedly upheld as valid union appeals procedures-including two steps of review by internal union boards or committees and a third step of review by a union-selected arbitrator-closely resembling the union internal remedy ruled out in Hudson. PERB has also taken the position that section 208(3) does not require any review of an objector's claims other than that available in an ordinary court action-a position that Hudson found insufficient to protect the rights of objectors.

If section $208(3)$ is to survive constitutional challenge in the wake of Hudson, it will have to be reinterpreted to require prompt review by an impartial decisionmaker of the objector's refund claim prior to any judicial review. This review may not be carried out by a union-selected arbitrator. It may, however, still be conducted in arbitration proceedings as long as the selection of the arbitrator does not represent the union's "unrestricted choice."63 Hudson leaves open the possibility of an arbitration remedy if the arbitrator is not selected by the union alone. Arbitrators selected by the union and the objecting

\footnotetext{
${ }^{62} I d$.

${ }^{63} 106 \mathrm{~S}$. Ct. at 1077 n. 21. In light of Hudson, PERB's rulings that the union may select the site of the arbitration and may group numerous objections into one hearing also become questionable.
} 
nonmember jointly, either by PERB or from a permanent list maintained by an arbitration organization approved for this purpose by PERB, might suffice.

Hudson also casts doubt on the validity of union procedures requiring two internal steps prior to resort to the arbitrator. Both steps are "initially controlled by the union which is an interested party" 64 and thus are not consistent with the due process required by the First Amendment. Moreover, requiring the exhaustion of internal appeals delays the presentation of the objector's complaint to an impartial decision-maker. Such delay is at odds with the requirement of prompt action. ${ }^{65}$

It is also doubtful whether the Court's requirement of "expeditious" review is satisfied by the current PERB rulings giving a union up to a year to reach a final decision on a nonmember's objections. The opinion does not present any time deadline, but a year seems a long time to wait. PERB will have to tighten the timetable for an arbitrator's review.

Finally, PERB must consider what role, if any, it can take in the review of objectors' claims. Although the Supreme Court in Hudson drew back from imposing a "full-dress administrative hearing, with evidentiary safeguards" as a constitutional mandate, an administrative agency could play an important role in resolving the questions raised by objectors' claims. Among the likely questions are what expenses may be taxed to objectors and how the share of union expenses not chargeable to objectors should be calculated. What is the proper union budgetary base? Is the union's financial statement properly prepared, certified, and audited? Are affiliated unions properly included? These questions are likely to occur in many cases, and unions and objectors alike would benefit from the greater consis-

\footnotetext{
${ }^{64}$ Id. at 1077.

65 Justice White's concurring opinion, joined by Chief Justice Burger, stated that a complaining nonmember should not be required to exhaust internal union procedures before going to arbitration. $I d$. at 1078 .
}

tency in the answers that an administrative determination would provide.

Moreover, the resolution of these issues will to a significant degree require legal determinations, including the constitutionality of permitting objectors to be charged certain expenses, assuring the independence of the decision-maker reviewing reduction claims, and the procedural sufficiency of the standards for calculating the agency fee share. An administrative agency should be involved in making these determinations either by articulating rules for the selection and guidance of neutrals, hearing and determining the contested cases, or reviewing the neutral's rulings.

As previously discussed, PERB has taken the position that whereas it may pass on the structure of a union's internal refund procedures, it lacks jurisdiction to review the accuracy of the refund itself. But substance and procedure are closely intertwined in such questions. Hudson's procedures flow directly from the substantive rights held to be at stake, and a part of the procedure required is an independent determination by an impartial decisionmaker prior to a union's use of contested fee payments. A contested agency fee payment is not analogous to a contested benefit under a collective agreement - the analogy PERB has drawn in justifying its noninvolvement in the review of the correctness of refunds. There is neither a statutory nor a constitutional interest in determining whether a particular benefit is paid or not paid; it is entirely a matter of private agreement between the employer and the union. By contrast, as Ellis and Hudson demonstrate, there is a significant constitutional interest in whether a particular expense is properly charged to a nonmember and in the procedures for considering a nonmember's refund claim.

\section{Conclusion}

The analysis in this paper suggests that Ellis and Hudson require PERB to take a more activist stance in policing the agency fee and protecting nonunion employee rights. PERB will have to issue guidelines, tracking Ellis's representation-relatedness 
standard and indicating what types of expenditures may be charged to nonmembers and what types may not; and PERB will have to take steps to assure that objectors are accorded procedural fairness.

These developments are fully consistent with the doctrinal framework articulated in Abood and the earlier Railway Labor Act cases. The Court's grounding of the agency fee in the anti-free rider principle tends to focus the range of permissible fee uses around collective bargaining. Its determination that agency fee payments impinge on constitutional rights implies the need for procedures that effectively protect objecting fee payers. Even though these conclusions flow naturally from the logic of the earlier cases, however, they raise new problems.

In Hudson, the agency shop fee deduction is viewed as a benefit authorized and implemented by the state and affecting the First Amendment interests of feepayers, and the Court has put the burden on the state to implement standards and procedures to protect the interests of objectors. Yet, in New York at least, the state agency with primary responsibility for public sector relations may not be comfortable with this task. PERB's decisions over the last decade indicate that it has little desire to engage in close review of the agency shop fee. PERB has generally declined to pass on the propriety of fee uses, to indicate clearly how the statutory requirement of a refund to objectors is to be satisfied, or to pass on the conduct or rulings of the unionappointed neutrals who have heard objectors' appeals. PERB's conclusion that it lacks jurisdiction to pass on the correctness of the amount of the refund is unpersuasive as an interpretation of the Civil Service Law but highly indicative of the Board's reluctance to become enmeshed in the issues raised by the agency shop fee.

PERB, like its counterpart agencies in other states, may be better suited to its primary mission of refereeing employerunion disputes than to vindicating the interests of nonunion employees. Ellis and (especially) Hudson thus create a sharp institutional dilemma for the Board. Its traditional statutory mandate requires it to maintain the confidence of public sector unions in order to be effective, whereas its new constitutional duties would force it to advance the position of objecting nonunionists at the expense of unions. Compelled to treat both public sector unions and nonunion employees as constituents in a context where the public employer has relatively little at stake and may, indeed, favor the union position as productive of peace and stability, the Board may be a hesitant champion of the nonunion employee's First Amendment rights. But there do not seem to be any other candidates available to serve as defenders of nonunionists' rights, and the Supreme Court has made the adequate defense of those rights the prerequisite to the state's authorization of public sector agency fees.

A reluctant state labor agency may be inadequate to the task newly mandated by the Supreme Court, but an aggressive agency could create other problems in terms of the autonomy of public sector unions. The promulgation and enforcement of substantive guidelines and procedures to protect objecting nonunionists necessarily entails state scrutiny of union operational and budgetary decisions. How public sector unions spend money in the course of bargaining, lobbying, and litigation against public employers, and how these unions allocate expenditures between the representation-related and non-representation-related categories, must now become subject to some form of state agency review. Union spending decisions will have to be made with PERB, or some other state body, in effect, looking over the union's shoulder.

The dilemma of having a state agency pass on how unions pursue these goals in conflicts with other state agencies may be inherent in the institutional position of state labor relations agencies, but the potential threat to union autonomy and effectiveness seems greater when the state labor board is authorized, indeed required, to review union budgetary decisions. 
These institutional difficulties in implementing Ellis and Hudson derive, at bottom, from the Supreme Court's requirement, articulated in Abood, that unions, labor boards, and courts be able to separate representation and bargaining from politics. Such differentiation is difficult even in the case of private sector unions. As the Supreme Court once acknowledged in the private sector context, "[L]abor's cause often is advanced on fronts other than collective bargaining and grievance settlement within the immediate employment context."66 In the public sector, the separation may be impossible to effect: "[C]ollective bargaining in the public sector is inherently political in any event. . . . Public sector unions' very right to organize and bargain, to say nothing of their ability to achieve significant gains through negotiations, inescapably involves political activity" (Rehmus and Kerner 1980:99).

In Abood the Supreme Court sought to recognize and reconcile the interests of unions and objecting employees - and the perspectives of collective bargaining and the First Amendment-through this distinction between politics and representation. What the distinction appeared to lack in logic it seemed to make up for in

${ }^{66}$ Eastex, Inc. v. NLRB, 437 U.S. 556, 565 (1978). pragmatic result: unions could collect fees so long as those fees were spent on representation and not politics. But the equilibrium of rights in Abood was achieved only through the Court's suspension of consideration of how the politics/representation distinction is to be drawn and enforced in actual cases. The Court's subsequent attention to the substance of that distinction in Ellis and the procedures for its vindication in Hudson resulted in a shifting in the balance of interests in favor of the objecting nonunion employee. Ellis and-especially-Hudson indicate that the Court's agency fee doctrine is increasingly driven by First Amendment concerns.

As the analysis in this study suggests, the full vindication of the Court's expanded view of objecting employees' First Amendment rights will turn on a strengthened role for state labor relations agencies like PERB. The irony apparent in predicating an enhanced government role on individual rights concerns may be overshadowed only by the difficulty of the task for state labor regulators: to be vigorous protectors of the rights of objecting employees without infringing on union autonomy and the rights of union workers. Only time, and future litigation, will tell how well they rise to meet this challenge.

\section{REFERENCES}

\section{Olson, Mancur}

1965 The Logic of Collective Action. Cambridge: Harvard University Press.

Rehmus, Charles M., and Benjamin A. Kerner

1980 "The Agency Shop After Abood: No Free Ride, But What's the Fare?" Industrial and
Labor Relations Review, Vol. 34, No. 1 (October), pp. 90-100.

Summers, Clyde W.

1975 "Public Sector Bargaining: Problems of Governmental Decisionmaking." University of Cincinnati Law Review, Vol. 44, No. 4, pp. 669-79. 